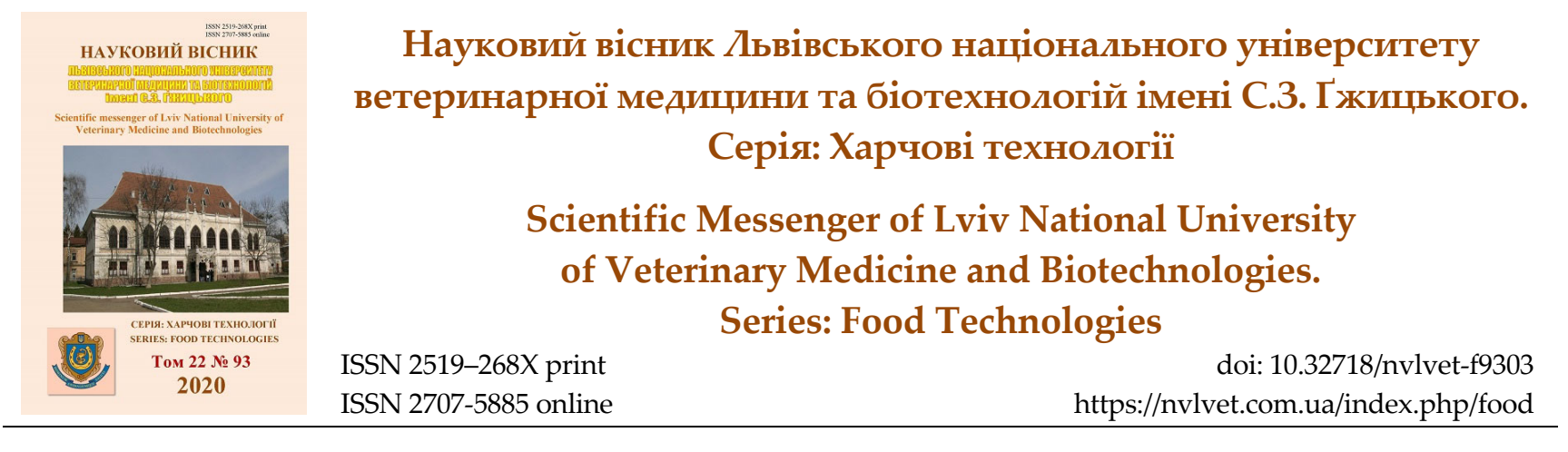

\title{
Technological Methods of Forming Thin Semiconductor Layers Part 3. Cathode Sputtering
}

\author{
B. Tsizh ${ }^{1,2}$, Z. Dziamski ${ }^{1}$ \\ ${ }^{1}$ Kazimierz Wielki University in Bydgoszcz, Bydgoszcz, Poland \\ ${ }^{2}$ Stepan Gzhytskyi National University of Veterinary Medicine and Biotechnologies Lviv, Ukraine
}

Article info

Received 23.01.2020

Received in revised form 24.02.2020

Accepted 25.02.2020

Kazimierz Wielki University in Bydgoszcz, 30 Chodkiewicza

Bydgoszcz, 85-064, Poland.

Stepan Gzhytskyi National University of Veterinary Medicine and Biotechnologies Lviv, ekarska Str., 50, Lviv 79010, Ukraine. Tel.: +38-032-239-26-35 E-mail: tsizhb@ukr.net
Tsizh, B., \& Dziamski, Z. (2020). Technological Methods of Forming Thin Semiconductor Layers. Part 3. Cathode Sputtering. Scientific Messenger of Lviv National University of Veterinary Medicine and Biotechnologies. Series: Food Technologies, 22(93), 15-17. doi: 10.32718/nvlvetf9303

The peculiarities and the basic technological ways of forming thin layers of semiconductor materials in vacuum by the method of thermal sputtering in quasi-closed volume are analyzed. The disadvantages of thermal deposition of thin films in open vacuum for multicomponent semiconductor compounds are indicated. We present designs of special collapsible evaporation chambers for quasi-closed volume thermal vacuum deposition, which contain the source material and the substrate in quasi-insulated conditions, and allow to create and control the necessary temperature ratios between the evaporator, substrate, walls and other structural elements. It is shown that the spatial distribution of temperature in the mentioned above chambers provides the evaporation (sublimation) of the starting material, the reflection of vapors from the heated walls, the intense exchange interaction between the gas phase and the condensation surfaces, which contributes to the diffusion mechanism of the transfer of matter and thermodynamically balanced process of film growth. It is shown that for all modifications the conditions of isolation of the localized volume and equilibrium of the condensation process are fulfilled to a greater or lesser extent by creating the required temperature gradient. However, it is problematic to use such designs for mass production because of their complexity and technological features. That is why, the method of thermal deposition of thin films in a quasi-closed volume is most often used in the manufacture of epitaxial single crystalline layers for research and experimental development, and for industrial production it is very effective to develop methods for obtaining thin films that combine on the one side universality of open vacuum, and on the other allow to approximate the processes of evaporation (sublimation) - condensation to thermodynamic equilibrium, for example, different variants of "hot walls". It is stated that the analyzed methods or their modifications are today a necessary means of creating thin-film semiconductor structures with predetermined properties. It is stated that the analyzed methods or their modifications are today a necessary means of creating thin-film semiconductor structures with predetermined properties.

Key words: thin films, semiconductors, technological methods of obtaining, condensation in a vacuum, thermal spraying, cathode sputtering.

\section{Технологічні способи формування тонких напівпровідникових шарів Частина 3. Катодне розпилення}

\author{
Б. Ціж ${ }^{1,2}$, 3. Дзямскі ${ }^{1}$
}

${ }^{1}$ Kazimierz Wielki University in Bydgoszcz, Bydgoszcz, Poland

${ }^{2}$ Львівський національний університет ветеринарної медицини та біотехнологій імені С. 3. Гжицького, м. Львів, Україна

\footnotetext{
Проаналізовано особливості нанесення напівпровідникових тонких плівок у вакуумі методом катодного розпилення. Вказано переваги і недоліки катодного розпилення для багатокомпонентних напівпровідникових сполук $і$ зазначено, ияо для можсливості отримання тонкоплівкових конденсатів із наперед заданими властивостями необхідно вдало поєднувати иі переваги і недоліки. Коротко охарактеризовано різновиди катодного розпилення у вакуумі, такі, як дво- $і$ триелектродне, реактивне, магнетронне,
} 
високочастотне йонно-плазмове. Представлено перелік найважливіших технологічних параметрів катодного розпилення і обтрунтовано їх вплив на властивості тонких плівок. Обгрунтовано необхідність застосування низькоенергетичних різновидів катодного розпилення для того, щоб вибивання окремих молекул з мімені не спричинило розкладання молекул на атоми і конденсати зберегли максимальну відповідність складу мімені. Зазначено, щзо особливо прецизійно слід мінімізувати за енергією технологічні режими катодного розпилення у випадку синтезу органічних напівпровідників із Ван-дер-Ваальсівськими міжмолекулярними хімічними зв'язками, і при ичьому слід формувати надійні суцільні мімені за розмірами електродів, наприклад, методом термічного спікання рідкофазних розчинів вихідних матеріалів. На основі проведеного аналізу зроблено висновок, щчо в ряді випадків метод катодного розпилення у вакуумі є універсальним і не замінимим способом формування напівпровідникових тонких плівок із наперед заданими специфічними властивостями.

Ключові слова: тонкі плівки, напівпровідники, технологічні методи отримання, конденсація у вакуумі, термічне напилення, катодне розпилення.

\section{Intrroduction}

In the first two parts of this review (Tsizh \& Dziamski, 2019), a brief description of the methods of producing thin films of inorganic semiconductors by different methods of thermal sputtering in vacuum was given, in particular, thermal sputtering in open vacuum, sputtering in quasi-closed volume, sputtering hot wall, etc. These methods, in comparison with others, have both significant advantages, such as high purity of synthesis, a wide range of variations in technological parameters of production, possibilities of industrial use and others, and disadvantages, such as non-equilibrium conditions for the growth of films, the dependence of the chemical composition of condensates on speed of deposition, deviation of the composition of films from stoichiometry, structural and technological complexity of execution in a number of cases. Therefore, from the very beginning of the usage of thin-film condensates in various industries and researches, the search was performed for new ways of obtaining thin-film condensates. One of such methods, based on fundamentally principles other than thermal spraying, is cathodic spraying in vacuum.

\section{Application of semiconductor films by cathodic sputtering in vacuum}

Cathode spraying is fundamentally different from all other methods of thin film deposition. The difference consists in the fact that the atoms or molecules of the vapor phase for condensate are knocked out by the bombardment of the starting material by accelerated electrically charged particles (ions and partially electrons) by transferring their momentum to the target surfaces. In this regard, thin films obtained by cathodic spraying have a number of characteristic properties, such as high adhesion and mechanical stability, preservation of the chemical composition of the source material and stoichiometry, continuity at low thicknesses, uniformity of crystalline structure and properties in thickness and thickness area, high accuracy and resolution of the topology of the drawing and others that distinguish them favorably from the condensates obtained by other methods. In addition, with this method of application one can be obtain much larger samples (by $1 \ldots 3$ orders of magnitude) than by thermal spraying of the velocity of particles flying from the source material during sputtering, provide the manufacture of multilayer structures in one technological cycle, combine film deposition operations and ion etching to obtain the necessary topology, etc. (Sharma \& Purohit, 1974;
Krishna, 2012; Sarkar, 2013; Bishop, 2016).

Today, many varieties of cathodic sputtering are known, such as two-electrode, three-electrode, highfrequency ion-plasma, magnetron, and others. The simplest form of the cathodic sputtering method is a twoelectrode scheme in which particles (molecules, or their groups) of the starting material are knocked out of the cathode by the bombardment of ionizing gas molecules (often argon) by the glow discharge (Chopra \& Das, 1983; Hotra, 2004; Antonyuk et al., 2016). However, due to the relatively high residual pressures of gases $\left(10^{2} \ldots 10^{1} \mathrm{~Pa}\right)$ during the technological process, the growth rate of films of semiconductor materials is insufficient for many tasks, and the condensates are substantially contaminated by the trapping of the bombarding ions. To reduce the pressure of the working gas and, thus, increase the rate of growth of the film and reduce the contamination of the condensate, as well as increase the adhesion caused by the higher energy of the sputtered particles and additional ionic cleaning of the substrate surface in the discharge plasma, the method of three-electrode cathode sputtering material is used, in which (target) is the third independent electrode under a large $(0.8 \ldots 2 \mathrm{kV})$ negative potential to provide the energy required to the ions that bombard it. To increase the discharge current and the density of the plasma ions, a thermocathode is used. To increase the rate of ionization and the formation of the desired configuration of the discharge plasma a magnetic field is used, which increases the probability of collision of electrons with gas molecules, thereby increasing the density of the plasma, as well as reducing the voltage between the cathode and the anode (up to $50 \ldots 500 \mathrm{~V}$, depending on the purity of the target and field values), which reduces the spraying of metal parts of the equipment. Cathodic spraying also allows the doping of thin films of semiconductor materials in the process of their growth by introducing into the composition of working chemically inert gas (most often Ar) various gases, such as oxygen, hydrogen sulfide, hydrogen chloride, etc. (Bunshah, 1994; Mattox, 2010; Frey \& Khan, 2015). Due to the above advantages of this method, a large number of varieties of cathodic sputtering systems of semiconductor materials, such as jet, magnetron, high-frequency, ion-beam, heteron, penning sputtering, ion deposition, and various combinations of their combinations have been developed (Bunshah, 1994; Kalynushkin et al., 2009; Kiyotaka et al., 2012; Frey \& Khan, 2015; Andrusevych et al., 2016; Shahinian, 2017), depending on the cathode configuration, methods of generation, transfer, 
acceleration and focusing of ions and other technological and structural factors.

However, along with a number of advantages of the cathodic spraying method, despite its many improvements, it has significant disadvantages, namely: low spraying speed, high residual pressures of working gases, condensation by foreign inclusions, the complexity of design and process control. In addition, due to the specific nature of the method (bombardment by highenergy ions, partial ionization of the vapor phase, etc.), thin films of semiconductor materials during cathodic spraying partially lose their sensitivity to external factors.

Thus, when applying thin films of semiconductor materials by the method of cathodic spraying, it is necessary to optimally combine its advantages and disadvantages, and to find those technological compromises that will allow to obtain condensates with predetermined properties. In particular, when forming multicomponent semiconductor condensates with low intermolecular bonding energy, such as chalcogenide glassy semiconductors, low energy varieties of cathodic sputtering should be used to prevent the knockdown of individual molecules from the target and to cause maximum decay. The technological modes of cathodic sputtering in the case of the synthesis of organic semiconductors with Van der Waals intermolecular chemical bonds should be particularly precisely minimized. In this case, reliable solid electrode size targets should be formed, for example, by thermal sintering of liquid-phase solutions of starting materials.

\section{Conclusions}

The features of deposition of semiconductor thin films in vacuum by the method of cathodic spraying are described. The advantages and disadvantages of cathodic sputtering for multicomponent semiconductor compounds are stated, and the fact that it is necessary to successfully combine these advantages and disadvantages in order to obtain thin-film condensates with predetermined properties. Briefly described are the varieties of cathodic sputtering in vacuum, such as two- and three-electrode, reactive, magnetron, high-frequency ion-plasma. The list of the most important technological parameters of cathode sputtering is presented and their influence on the properties of thin films is substantiated. The necessity of using low energy varieties of cathodic sputtering is substantiated so that the ejection of individual molecules from the target does not cause the molecules to decompose into atoms and the condensates retain the maximum correspondence of the target composition. On the basis of the above, we can conclude that in some cases the method of cathodic sputtering in vacuum is a universal and irreplaceable way of forming semiconductor thin films with predetermined specific properties.

\section{References}

Andrusevych, A. O., Gurin, D. V., \& Malaya, I. N. (2016). Analiz metodiv otrymannia nanostrukturovanyh dielektrychnyh plivok. Tehnologiya priborostroyeniya. 3, 7-
10. http://journal.nitip.com.ua/media/uploads/documents/ 23 16.pdf (in Ukrainian).

Antonyuk, V. S., Tymchyk, G. S., Bondarenko, Yu. Yu., Kovalenko, Yu. I., Bondarenko, M. O., \& Gaydash R.P. (2016). Pokryttia u pryladobuduvanni : monografiya. Kyiv, NTUU "KPI". http://ena.lp.edu.ua: 8080/handle/ntb/36387 (in Ukrainian).

Bishop, C. A. (2016) Vacuum Deposition onto Webs, Films and Foils. New York, William Andrew Publication. doi: 10.1016/C2013-0-14249-3.

Bunshah, R. F. (1994). Handbook of Deposition Technologies for Films and Coatings. Edited by New Jersey, Noyes Publication. https://www.elsevier.com/books/ handbook-of-deposition-technologies-for-films-andcoatings/bunshah/978-0-8155-1337-7.

Chopra, K. L., \& Das, S. R. (1983). Thin Film Solar Cells. New York, Plenum Press. https://www.springer. com/gp/book/9780306411410.

Frey, H., \& Khan, H. R. (2015). Handbook of Thin Film Technology. Heidelberg, Springer-Verlag Berlin Heidelberg. https:/www.springer.com/us/book/9783642054297

Hotra, Z. Yu. (2004). Fizychni osnovy elektronnoyi tehniky. Lviv, Beskyd Bit. (in Ukrainian).

Kalynushkin, Ye. P., Fedorkova, N. M., \& Synytsina, Yu. P. (2009). Tonkoplivkovi materialy ta tehnologiyi yih oderzhannia. Dnipropetrovs'k, NMetAU (in Ukrainian).

Kiyotaka, W., Isaku, K., \& Hidetoshi, K. (2012). Handbook of Sputter Deposition Technology. New York, William Andrew Publication. doi: 10.1016/C2010-067037-4.

Krishna, S. (2012). Handbook of Thin Film Deposition. New York, William Andrew Publication. doi: 10.1016/C2009-0-64359-2.

Mattox, D. M. (2010). Handbook of Physical Vapor Deposition (PVD) Processing. New York, William Andrew Publication. doi: 10.1016/C2009-0-18800-1.

Sarkar, J. (2013). Sputtering Materials for VLSI and Thin Film Devices. New York, William Andrew Publication. https://www.elsevier.com/books/sputteringmaterials-for-vlsi-and-thin-film-devices/sarkar/978-08155-1593-7.

Shahinian, L. R. (2017). The Mechanisms of Formation of Thin Films and Coatings Deposited by Physical Vapor Deposition Technology. Kyiv, Akademperiodyka. http://akademperiodyka.org.ua/en/books/the_mechanism s_of_formation_of_thin_films_and_coatings_deposited_ by_physical_vapor_deposition_technology.

Sharma, B. L., \& Purohit R. K. (1974). Semiconductor heterojunctions. New York, Pergamon Press. https:/www.worldcat.org/title/semiconductorheterojunctions/oclc/742483550.

Tsizh, B. \& Dziamski Z. (2019). Technological Methods of Forming Thin Semiconductor Layers. Part 2. Scientific Messenger LNUVMB. Series: Food Technologies, 21(92), 3-7. doi: 10.32718/nvlvet-f9201.

Tsizh, B., \& Dziamski, Z. (2019). Technological Methods of Forming Thin Semiconductor Layers. Part 1. Scientific Messenger LNUVMB. Series: Food Technologies, 21(91), 20-24. doi: 10.32718/nvlvet-f9104. 